\title{
Heme Oxygenase-1-Related Carbon Monoxide and Flavonoids in Ischemic/Reperfused Rat Retina
}

\author{
Marta E. Szabo, ${ }^{1,2}$ Eva Gallyas, ${ }^{1}$ Istvan Bak, ${ }^{2}$ Andry Rakotovao, ${ }^{3}$ Francois Boucher, ${ }^{3}$ \\ Joel de Leiris, ${ }^{3}$ Norbert Nagy, ${ }^{2}$ Edit Varga, ${ }^{2}$ and Arpad Tosaki ${ }^{2}$
}

Purpose. There is increasing evidence to show cytoprotective effects of various flavonoid-rich extracts and the tissue-protective capacity of flavonoid-rich extract of sour cherry is due to flavonoid components of seeds. Sour cherry seed flavonoids were evaluated for their contribution to postischemic recovery related to endogenous carbon monoxide (CO) production in rat retinas subjected to ischemia/reperfusion.

Methods. Rats were orally treated with selected doses of flavonoid-rich extract of sour cherry seeds for 2 weeks. Animals were anesthetized, and a suture was placed behind the globe including the central retinal artery. Next, retinas were subjected to 90 minutes of ischemia followed by 24 hours of reperfusion. After this procedure, heme oxygenase-1 (HO-1)related protein expression and enzyme activity, HO-1-related endogenous $\mathrm{CO}$ production, and ionic imbalance including tissue $\mathrm{Na}^{+}, \mathrm{K}^{+}$, and $\mathrm{Ca}^{2+}$ in untreated and treated ischemic/ reperfused retinas were measured.

RESULTS. Retinal ischemia/reperfusion resulted in a significant reduction (to $10 \%$ ) in $\mathrm{HO}-1$ protein expression, enzyme activity, and $\mathrm{HO}-1$-related endogenous $\mathrm{CO}$ production in the retina. These changes were accompanied by increases in retinal $\mathrm{Na}^{+}$ and $\mathrm{Ca}^{2+}$ gains and loss of $\mathrm{K}^{+}$. In rats treated with 10 and 30 $\mathrm{mg} / \mathrm{kg}$ of sour cherry flavonoid-rich extract, after 24 hours of reperfusion, tissue $\mathrm{Na}^{+}$and $\mathrm{Ca}^{2+}$ accumulation and $\mathrm{K}^{+}$loss were prevented in comparison with the drug-free control.

Conclusions. Sour cherry seed flavonoid-rich extract showed a protective effect against reperfusion-induced injury through its ability to reduce the changes in concentrations of retinal ions through $\mathrm{HO}-1-$ related endogenous $\mathrm{CO}$ production in the ischemic/reperfused retina. (Invest Ophthalmol Vis Sci. 2004;45: 3727-3732) DOI:10.1167/iovs.03-1324

$\mathrm{T}$ he discovery of endothelium-derived relaxing factor (EDRF) in the 1970s and its identification as nitric oxide (NO) in the late 1980 s revealed a novel role for endogenous gaseous compounds, including $\mathrm{NO}$ as mediators of diverse and critical effects on an enormous range of cellular and organ functions. It has also been known for

From the ${ }^{1}$ Clinic of Ophthalmology, Health and Science Center, University of Szeged, Szeged, Hungary; the ${ }^{2}$ Department of Pharmacology, Health and Science Center, University of Debrecen, Debrecen, Hungary; and the ${ }^{3}$ University of Joseph Fourier, Grenoble, France.

Supported by grants from the ETT $(62 / 2001)$ and OTKA (T-46145), Hungary, and the Hungarian-French TET (F-32/03) collaborative grant.

Submitted for publication December 9, 2003; revised May 25, 2004; accepted July 12, 2004

Disclosure: M.E. Szabo, None; E. Gallyas, None; I. Bak, None; A. Rakotovao, None; F. Boucher, None; J. de Leiris, None; N. Nagy, None; E. Varga, None; A. Tosaki, None

The publication costs of this article were defrayed in part by page charge payment. This article must therefore be marked "advertisement" in accordance with 18 U.S.C. $\$ 1734$ solely to indicate this fact.

Corresponding author: Arpad Tosaki, Department of Pharmacology, Health and Science Center, University of Debrecen, Nagyerdei krt. 98, 4032-Debrecen, Hungary; tosaki@king.pharmacol.dote.hu. some time that in addition to NO, another gaseous molecule, carbon monoxide (CO) is generated under physiological conditions. In viable cells and organs the heme oxygenase $(\mathrm{HO})$ enzyme system is primarily responsible for $\mathrm{CO}$ production. $^{1,2}$

Adaptation of cells and tissues to ischemia or hypoxia is of fundamental importance in developmental, physiological, and pathophysiological processes. Cells, tissues, and organs of humans and other mammals respond to low oxygen tension in part by finely tuned expression of a group of physiologically relevant genes, proteins, and enzymes. The microsomal heme oxygenase (HO), originally identified by Tenhunen et al., ${ }^{3}$ catalyzes the oxidative degradation of heme to biliverdin, which is subsequently converted to bilirubin by biliverdin reductase. ${ }^{3,4}$ Mammalian heme oxygenase, which catabolizes cellular heme to biliverdin, carbon monoxide (CO), and free iron, is represented by three isoforms, HO-1, -2, and -3 encoded by separate genes. HO-3, which in its primary structure resembles $\mathrm{HO}-2$, is marginally active. ${ }^{5}$ Evidence has recently accumulated suggesting that $\mathrm{CO}$ generated by $\mathrm{HO}$ may be a physiological signaling molecule. $^{6,7}$ HO may also function as an antioxidant defense mechanism, a possibility suggested on the basis of its marked upregulation in stressed cells, ${ }^{8,9}$ including those in tissue subjected to ischemia/reperfusion. One important interpretation of the aforementioned findings is that HO-1 may serve as a key endogenous factor in the adaptation and/or defense against oxidative and cellular stress. Thus, it is reasonable to assume that a relationship may exist between the HO system and endogenous CO production. Keyse and Tyrrell $^{8}$ showed that expression of HO-1 is also substantially induced by a variety of molecules causing oxidative stress. Consequently, many investigators have recently focused their attention on the role, function, and regulation of HO1 -related endogenous $\mathrm{CO}$ formation in various in vivo and in vitro models. Although the function of HO-1 has recently been extensively studied at the cellular level, comparatively little attention, to our knowledge, has been given to $\mathrm{HO}-1-$ related endogenous $\mathrm{CO}$ production in the ischemic/reperfused retina. In a previous study, Bak et al. ${ }^{10}$ observed a reduction in HO-1 mRNA expression and enzyme activity in ischemic/reperfused myocardium. This finding led us to speculate that the reduction in HO-1 mRNA expression may change the endogenous $\mathrm{CO}$ production in ischemic/reperfused retina. If this is the case, HO-1-regulated endogenous CO production and its vasodilator or cytoprotective activity may play a role in the control of reperfusion-induced retinal damage. The overall objectives of the present investigation were to study: (1) formation of endogenous CO levels using gas chromatography, (2) the role of $\mathrm{HO}-1$ protein expression and endogenous $\mathrm{CO}$ production on reperfusion, and (3) the effect of flavonoid-rich extract obtained from the seed of sour cherry on HO-1 protein expression, enzyme activity, endogenous tissue $\mathrm{CO}$ formation, and tissue $\mathrm{Na}^{+}, \mathrm{K}^{+}$, and $\mathrm{Ca}^{2+}$ contents, in ischemic/reperfused retina. 


\section{Methods}

\section{Ischemia and Reperfusion}

Rats were anesthetized with pentobarbital $(60 \mathrm{mg} / \mathrm{kg}$, intraperitoneally), and the central retinal artery was occluded as described in detail elsewhere. ${ }^{11}$ In brief, the pupils were maximally dilated with atropine sulfate (1\%) administered drop-wise, and lids were retracted by sutures. At the onset of each experiment peritomy was performed, and a traction-type occluder consisting of a silk suture thread through a polyethylene guide cannula was used for retinal artery occlusion. The suture was positioned behind the globe loosely around the optic nerve, central retinal artery, ciliary arteries, and the retrobulbar connective tissue using an operating microscope. Regional ischemia could be induced as desired by pulling the suture while pressing the tube against the surface of the optic nerve. Ischemia may then be maintained for any desired length of time by clamping the tube and the suture. After the designated period of ischemia, release of the occluder results in reperfusion of the eye. The successful induction of ischemia and the adequacy of reperfusion were confirmed visually by an ophthalmoscope. All animals were handled and received humane care in compliance with the ARVO Statement for the Use of Animals in Ophthalmic and Vision Research and the NIH Guidelines. The institutional review board of the University of Debrecen, Hungary, approved the research.

\section{Measurement of Tissue CO Content}

Retinal CO content was measured using a gas chromatograph, as previously described. ${ }^{12}$ After 90 minutes of ischemia followed by 24 hours of reperfusion, retinas were removed from rat eyes and homogenized in 4 volumes of $0.1 \mathrm{M}$ phosphate buffer $(\mathrm{pH} 7.4)$ using a homogenizer (model X520; Ingenieurburo CAT; M. Zipperer GmbH, Staufen, Germany) at $4^{\circ} \mathrm{C}$ to $7^{\circ} \mathrm{C}$. Homogenates were centrifuged at $4^{\circ} \mathrm{C}$ for 15 minutes at $12,800 \mathrm{~g}$, and the supernatant fractions were used for the determination of tissue CO. Reaction mixtures contain $150 \mu \mathrm{L}$ of supernatant, $60 \mu \mathrm{L}$ of NADPH ( $4.5 \mathrm{mM})$ and $50 \mu \mathrm{L}$ of $3.5 / 0.35 \mathrm{mM}$ methemalbumin (a mixture [1:10] of hemin [Sigma-Aldrich, St. Louis, $\mathrm{MO}$ ] and bovine serum albumin [Sigma-Aldrich], and for blank samples $60 \mu \mathrm{L}$ phosphate buffer was added instead of NADPH. Samples were preincubated at $37^{\circ} \mathrm{C}$ for 5 minutes, and the headspace was purged and the incubation continued for 1 hour in the dark at $37^{\circ} \mathrm{C}$. The reaction was stopped by placing the samples on ice and the headspace gas was analyzed. One thousand microliters of the headspace gas from each vial was injected into the gas chromatograph with a gas-tight syringe (volume, $2.5 \mathrm{~mL}$; Hamilton Co., Reno, NV) in argon gas flow with a speed of $20 \mathrm{~mL} / \mathrm{min}$. Analysis took place during the next 90 seconds on a $240-\mathrm{cm}$ stainless-steel column with a $0.3-\mathrm{cm}$ inner diameter. Values were expressed in microvolts, then peak areas were integrated and expressed in arbitrary units. The column was packed with mesh (Chromosorb 80/100, 10\% Carbowax $20 \mathrm{M}$; both from Supelco, Budapest, Hungary; $3.5 \% \mathrm{KOH}$ ) and maintained at $120^{\circ} \mathrm{C}$. The temperature of the column and the injector was controlled and kept at $150^{\circ} \mathrm{C}$.

\section{Western Blot Analysis}

Detached retinas were homogenized in Tris- $\mathrm{HCl}(13.2 \mathrm{mM} / \mathrm{L})$, glycerol (5.5\%), SDS (0.44\%), and $\beta$-mercaptoethanol. The same amount of soluble protein $(50 \mu \mathrm{g})$ was fractionated by Tris-glycine-SDS-polyacrylamide gel (12\%) electrophoresis, and Western blot was performed as described by Pellacani et al. ${ }^{13}$ with the use of an antibody to recombinant rat HO-1 protein (1:1000; StressGen, Victoria, British Columbia, Canada). The relative HO-1 protein expression was analyzed by densitometry.

\section{HO Activity Assay}

At the end of reperfusion, the retinal tissue was homogenized in $10 \mathrm{~mL}$ of $200 \mathrm{mM}$ phosphate buffer, and the homogenate was centrifuged at $19,000 \mathrm{~g} 4^{\circ} \mathrm{C}$ for 10 minutes. The supernatant was removed and recen- trifuged at $100,000 \mathrm{~g} 4^{\circ} \mathrm{C}$ for 60 minutes, and the precipitated fraction was suspended in $2 \mathrm{~mL}$ of $100 \mathrm{mM}$ potassium phosphate buffer. Biliverdin reductase was crudely purified by the technique of Tenhunen et al. ${ }^{4} \mathrm{HO}$ activity was assayed as described by Yoshida et al. ${ }^{14}$ Reaction mixtures consisted of $100 \mu \mathrm{M}$ potassium phosphate ( $\mathrm{pH} 7.4$ ), $15 \mathrm{nM}$ hemin, $300 \mu \mathrm{M}$ bovine serum albumin, $1 \mathrm{mg}$ biliverdin reductase, and 1 to $2 \mathrm{mg}$ microsomal fraction of retinal tissue (final volume of $2 \mathrm{~mL}$ ). The reaction was allowed to proceed for 1 hour at $37^{\circ} \mathrm{C}$ in the dark in a shaking water bath and was stopped by placing the test tube on ice. Incubation mixtures were then scanned using a scanning spectrophotometer, and the amount of bilirubin was calculated as the difference between absorbance at 464 and $530 \mathrm{~nm} .{ }^{15}$ Protein content was determined with Folin-phenol reagent according to Lowry et al. ${ }^{16}$ in the microsomal fraction.

\section{Measurement of Retinal $\mathrm{Na}^{+}, \mathrm{K}^{+}$, and $\mathrm{Ca}^{2+}$ Contents}

At the end of the reperfusion period (after 24 hours), rats were reanesthetized with pentobarbital $(60 \mathrm{mg} / \mathrm{kg}$ intraperitoneally), the chest was opened, and a perfusion cannula was inserted through the heart into the aorta. The right ventricle of the heart was opened, and the blood was allowed to escape. Cold $\left(6-11^{\circ} \mathrm{C}\right) \mathrm{Na}^{+}-, \mathrm{K}^{+}$, and $\mathrm{Ca}^{2+}$-free solution containing $100 \mathrm{mM}$ of trishydroxymethylaminomethane and $220 \mathrm{mM}$ of sucrose (pH adjusted at $7.4 \mathrm{by} \mathrm{HCl}, \mathrm{pO}_{2}$ and osmolality were 0 to $4 \mathrm{kPa}$ and 300 to $330 \mathrm{mOsmol} / \mathrm{g}$, respectively) was used to wash out ions and blood from the vasculature and extracellular space and to stop or at least reduce the activity of membrane enzymes responsible for various membrane ion transports in the retina. Two hundred milliliters of cold buffer washed out more than $90 \%$ of the ions from the extracellular space. ${ }^{17}$ As described previously, ${ }^{18}$ a short (30 seconds) washout period was optimal because a prolonged cold perfusion may cause artifacts in ion distributions and destruction of retinal tissue. Immediately after the washout period, the eye was enucleated and rapidly opened, and the retina was progressively detached from the retinal epithelium and finally dissociated by cutting from the optic nerve. ${ }^{19}$ Retinal tissue was dried for 48 hours at $100^{\circ} \mathrm{C}$ and then converted to ash at $550^{\circ} \mathrm{C}$ for 24 hours. The ash was dissolved in $0.2 \mathrm{~mL}$ of $3 \mathrm{M}$ nitric acid and diluted 10-fold with deionized water. Tissue $\mathrm{Na}^{+}$was measured at a wavelength of $330.3 \mathrm{~nm}, \mathrm{~K}^{+}$at 404.4 $\mathrm{nm}$, and $\mathrm{Ca}^{2+}$ at $422.7 \mathrm{~nm}$ in an air acetylene flame by an atomic absorption spectrophotometer (Perkin-Elmer, Wellesley, MA). The washout perfusion method and the determination of tissue ion contents have been described previously in different tissue. ${ }^{20}$ Because a small amount of extracellular ions can contaminate the samples after washing out the extracellular space, ${ }^{17}$ the values obtained in our studies are termed retinal rather than intracellular ion contents.

\section{Histology}

In additional studies, for the fixation of retina, a cannula was introduced through the heart into the aorta, and the right ventricle of the heart was opened to allow blood to escape. For washout of blood before fixation, a buffered solution of $0.9 \% \mathrm{NaCl}(100 \mathrm{~mL})$ was used. A short (approximately 20 seconds) washout period was optimal, because prolonged perfusion before fixation may cause artifacts (e.g., edema formation) in the nervous tissue. One hundred milliliters of the fixative solution (Bouin's solutions) followed immediately without any interruption of the $\mathrm{NaCl}$ perfusion. Then eyes were enucleated, rapidly cut open, and divided in half by coronal section through the ora serrata. The vitreous was removed, and the eye was immersed in fixative solution (Bouin's fluid). After fixation, the tissue was dehydrated in graded series of ethanol and embedded in paraffin. Sagittal sections of $7 \mu \mathrm{m}$ were cut and stained with hematoxylin-eosin. Ischemia/reperfusion-induced cell swelling (edema formation) is well recognized and documented in the inner plexiform layer of the retina. ${ }^{21,22}$ The average of the retina's thickness for each eye was measured in the sagittal section at near the optic nerve, and expressed in micrometers using a video-plan computer analyzer (Imstar, Paris, France) as we 
previously described. ${ }^{11}$ Migration of neutrophils was observed after 90 minutes of ischemia followed by 24 hours of reperfusion.

\section{Experimental Time Course}

Before the onset of ischemia and reperfusion and the isolation of retina, rats were treated orally with 5,10 , or $30 \mathrm{mg} / \mathrm{kg}$ per day of the sour cherry seed flavonoids for 14 days. After 14 days' pretreatment, eyes were subjected to 90 minutes of ischemia followed by 24 hours of reperfusion. At the end of reperfusion period, HO-1 protein expression, $\mathrm{HO}$ enzyme activity, HO-1-related $\mathrm{CO}$ production, and retinal $\mathrm{Na}^{+}, \mathrm{K}^{+}$, and $\mathrm{Ca}^{2+}$ contents were measured in untreated and drug treated groups. Our study had two single objectives: the first was to study the HO-1 related CO production in ischemic/reperfused retina. The second objective of our work was to evaluate the degree to which flavonoid-rich extract of sour cherry seeds may attenuate the changes of retinal ion contents induced by ischemia/reperfusion.

The extract of sour cherry was produced by Papp Ltd. (Nyirtass, Hungary). UV and gas chromatography-mass spectrometry analyses in conjunction with HPLC showed that this novel sour cherry seed extract is $4 \%$ flavonoids, including quercetin, apigenin, rhamnetin, scutellacein, and pinocembrin. This fraction was called the sour cherry flavonoid-rich extract and used in our study. However, sour cherry seeds were extracted using various steps and analyzed. Thus, sour cherry seeds contain $37 \%$ of vegetable oil (triglycerides, oleic acids, $\alpha$-tocopherol, tocotrienols, and tocopherol-like components) and $63 \%$ of solid components of various molecular structures. The $4 \%, 4 \%, 4 \%$, $3 \%, 2 \%, 1 \%$, and $1 \%$ of the $63 \%$ solid components of sour cherry seed extract are cianids, polyphenols, flavonoids, acids, pro- and anthocyanidines, stilbanes, and catechins, respectively.

The flavonoid-rich fraction of sour cherry seed extract was homogenized in $2 \mathrm{~mL}$ of $1 \%$ methylcellulose solution and then diluted with $0.9 \%$ of $\mathrm{NaCl}$ to $10 \mathrm{~mL}$. Rats were orally treated daily with $10 \mathrm{~mL} / \mathrm{kg}$ of the solution (containing 5,10 , or $30 \mathrm{mg} / \mathrm{kg}$ of flavonoid-rich extract) for 14 days, and no changes in the behavior and physical activities of animals were observed during the treatment.
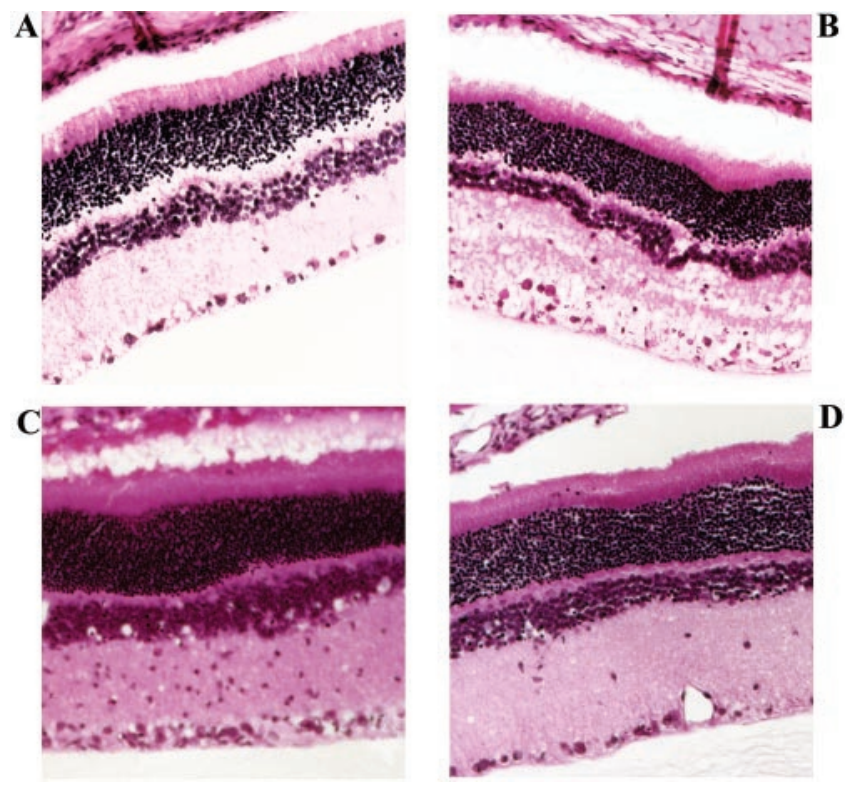

FIGURE 1. Sagittal sections of rat retinas showing layer structures of nonischemic control (A), retina subjected to 90 minutes of ischemia followed by 24 hours of reperfusion (B), retina from rats treated with $10 \mathrm{mg} / \mathrm{kg}$ of sour cherry flavonoid-rich extract for 10 days and eyes subjected to 90 minutes ischemia followed by 24 hours reperfusion (C), and retina from rats treated with $30 \mathrm{mg} / \mathrm{kg}$ of sour cherry flavonoid-rich extract obtained for 14 days, and eyes subjected to 90 minutes ischemia followed by 24 hours of reperfusion (D).

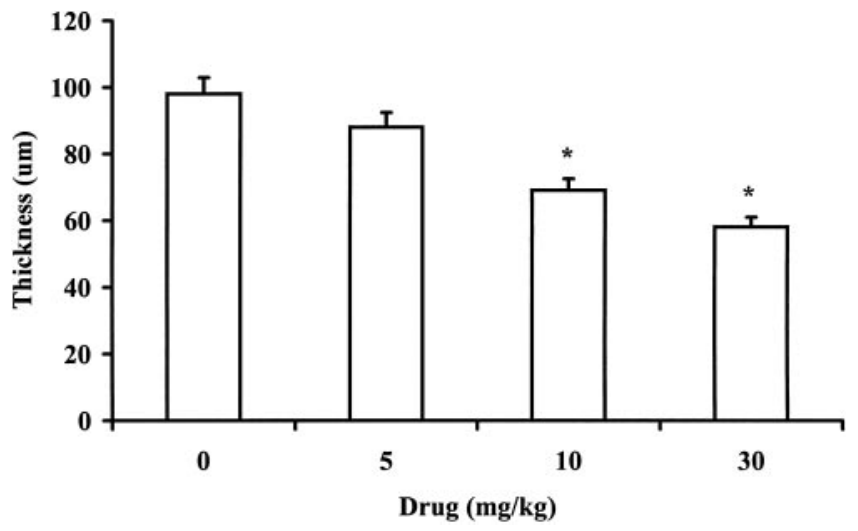

Figure 2. The effect of flavonoid-rich extract of sour cherry on the extent of retinal edema indicating by the thickness (in micrometers) of the inner plexiform layer in ischemic/reperfused eyes. Eyes were subjected to 90 minutes of ischemia followed by 24 hours of reperfusion. $n=6$ in each group, mean $\pm \mathrm{SEM}$. Comparisons were made to the drug-free thickness. ${ }^{*} P<0.05$.

\section{Statistics}

Gaussian-distributed variables were expressed as the mean \pm the SEM of $\mathrm{CO}$ production, $\mathrm{HO}$ enzyme activity, cations, and the thickness (in micrometers) of the inner plexiform layer. Nonparametric distribution $\left(\chi^{2}\right.$ test) for neutrophil leukocyte migration was used and classified as the presence or absence of neutrophil leukocytes.

\section{Results}

Figure 1 shows the sagittal section of rat retina in nonischemic control eye (Fig. 1A), in retina subjected to 90 minutes ischemia followed by 24 reperfusion without treatment (Fig. 1B), in ischemic/reperfused ( 90 minutes/24 hours) retina treated with 10 (Fig. 1C) and 30 (Fig. 1D) $\mathrm{mg} / \mathrm{kg}$ sour cherry seed extract for 14 days, respectively. In the drug-free ischemic/ reperfused retina (Fig. 1B), we observed many changes by using hematoxylin-eosin staining in the inner nuclear layer. There were more pyknotic, vacuolated spaces and degenerative changes in ganglion cells. These changes were markedly reduced in retinas subjected to ischemia/reperfusion and treated with 10 (Fig. 1C) and 30 (Fig. 1D) $\mathrm{mg} / \mathrm{kg}$ sour cherry flavonoid-rich seed extract.

Figure 2 shows the thickness (in micrometers), as an indicator of edema formation, of the retinal plexiform layer in eyes subjected to 90 minutes of ischemia followed by 24 hours of reperfusion in drug-free and drug-treated groups. Thus, a significant reduction in the thickness of the inner plexiform layer was observed in the ischemic/reperfused retina obtained from rats treated with 10 and $30 \mathrm{mg} / \mathrm{kg}$ of sour cherry flavonoid-rich extract, respectively (Fig. 2). The migration of neutrophils was reduced by $75 \%$ in the groups treated with $30 \mathrm{mg} / \mathrm{kg}$ sour cherry flavonoid-rich extract.

Figure 3 shows representative chromatograms of CO peaks recorded (Fig. 3, chromatogram $\mathrm{A}$ ) in the nonischemic retina; and after 90 minutes of ischemia followed by 24 hours of reperfusion (Fig. 3, chromatogram E) in the drug-free retina; and in retina from rats treated with (Fig. 3, chromatogram B) $30 \mathrm{mg} / \mathrm{kg}$, (Fig. 3 chromatogram C) $10 \mathrm{mg} / \mathrm{kg}$, or (Fig. 3 chromatogram D) $5 \mathrm{mg} / \mathrm{kg}$ flavonoid-rich sour cherry seed extract. Thus, the results clearly show that detectable endogenous $\mathrm{CO}$ production by GC can be observed in aerobically perfused rat retina (Fig. 3, chromatogram A), and this CO peak was substantially reduced in ischemic/reperfused drug-free retina (Fig. 3, chromatogram E). However, in the ischemic/reper- 


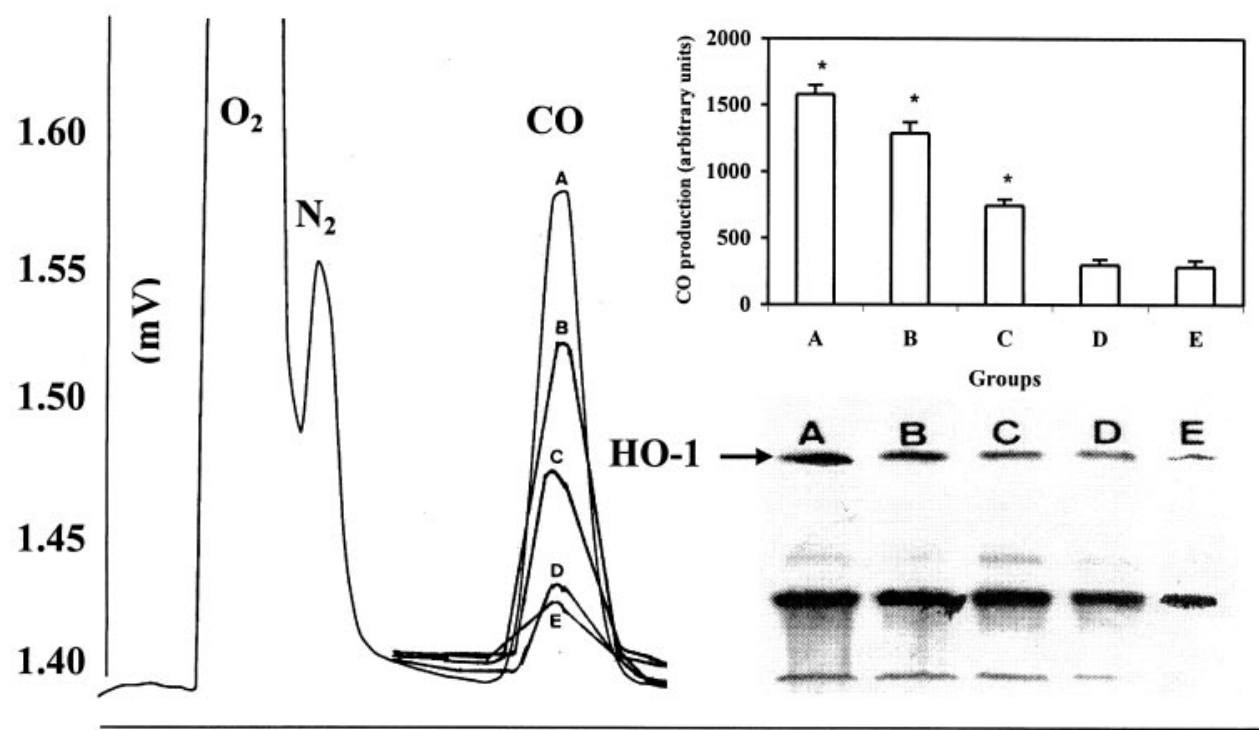

1.0
2.0
1.5

Running time (min for GC analysis)
Figure 3. GC chromatograms for the demonstration of endogenous $\mathrm{CO}$ production in rat retina subjected to 90 minutes of ischemia followed by 24 hours of reperfusion. Chromatogram A shows CO production in intact retina, and chromatogram $\mathrm{E}$ represents tissue $\mathrm{CO}$ production in retina subjected to 90 minutes ischemia followed by 24 hours of reperfusion. Rats were treated with 30 (B), 10 (C), or 5 (D) $\mathrm{mg} / \mathrm{kg}$ flavonoid-rich sour cherry extract for 14 days. Then eyes were subjected to ischemia/reperfusion, and chromatograms were registered at the end of reperfusion period. Insets show the corresponding (A, B, C, D, and $\mathbf{E}$ ) levels of CO production (top inset, in arbitrary units, mean \pm SEM of five experiments in each group) and representative Western blot analysis of HO-1 protein expression (bottom). ${ }^{*} P<0.05$ in comparison with the ischemic/reperfused (E) drug-free control values. fused retina, a moderate increase in endogenous $\mathrm{CO}$ production was measured in rats treated with 30,10 , or $5 / \mathrm{kg}$ sour cherry flavonoid-rich extract, respectively, returning toward the concentration observed in the Figure 3, chromotogram A.

Insets in the Figure 3 (top) show the corresponding integrated and calculated peak areas ( $n=5$ in each group) of CO curves expressed in arbitrary units in nonischemic control (Fig. $3 \mathrm{~A})$ retinas, in retinas obtained from rats treated with $30 \mathrm{mg} / \mathrm{kg}$ (Fig. 3B; ${ }^{*} P<0.05$ ), $10 \mathrm{mg} / \mathrm{kg}$ (Fig. 3C; ${ }^{*} P<0.05$ ), or $5 \mathrm{mg} / \mathrm{kg}$ (Fig. 3D) sour cherry flavonoid-rich extract, respectively, and subjected to 90 minutes of ischemia followed by 24 hours of reperfusion.

Insets in the Figure 3 show (bottom) the expression of HO-1 protein in nonischemic aerobic control retina (Fig. 3, lane A), in ischemic/reperfused drug-free control retina (Fig. 3, lane E), in ischemic/reperfused retina obtained from rats treated with 30 (Fig. 3, lane B), 10 (Fig. 3, lane C), or 5 (Fig. 3, lane D) mg/kg flavonoid-rich extract. Thus, a downregulation in HO-1 protein expression (approximately 10-fold) was observed in ischemic/ reperfused retina (Fig. 3, lane E) in comparison with the aerobically perfused nonischemic control retina (Fig. 3, lane A). In rats treated with 5,10 , or $30 \mathrm{mg} / \mathrm{kg}$ sour cherry seed flavonoid-rich extract and retinas were subjected to 90 minutes ischemia followed by 24 hours of reperfusion, the expression of HO-1 mRNA was increased approximately 1.5-, 5-fold, and 9-fold, respectively, in comparison with the ischemic/reperfused drug-free value.

HO enzyme activity (Fig. 4) was significantly reduced after 24 hours of reperfusion in drug-free ischemic/reperfused retinas (Fig. 4, group 2) in comparison with the nonischemic group (Fig. 4, group 1). However, a significant increase in $\mathrm{HO}$ enzyme activity was observed in retinas (Fig. 4, group 3 and group 4) treated with 10 or $30 \mathrm{mg} / \mathrm{kg}$ of flavonoid-rich sour cherry seed extract, respectively, compared with the ischemic/ reperfused drug-free control group.

The effect of sour cherry flavonoid-rich seed extract was tested in rat retina for its protective action against the changes of retinal cation contents induced by 90 minutes ischemia followed by 24 hours of reperfusion. Table 1 shows the basic levels of retinal $\mathrm{Na}^{+}, \mathrm{K}^{+}$, and $\mathrm{Ca}^{2+}$ contents (first column) in nonischemic retinas. After 90 minutes of ischemia followed by 24 hours of reperfusion, there was a significant increase in retinal $\mathrm{Na}^{+}$and $\mathrm{Ca}^{2+}$ contents from nonischemic control levels of $51.7 \pm 2.8$ and $2.1 \pm 0.1 \mu \mathrm{g} / \mathrm{g}$ dry weight to $94.2 \pm 3.2$ and $4.8 \pm 0.2 \mu \mathrm{g} / \mathrm{g}$ dry weight, respectively. Tissue $\mathrm{K}^{+}$was reduced from the nonischemic control value of $303.4 \pm 5.1$ to $229.6 \pm 4.2 \mu \mathrm{g} / \mathrm{g}$ dry weight $\left({ }^{*} P<0.05\right)$. These changes in ischemia/reperfusion-induced retinal $\mathrm{Na}^{+}$and $\mathrm{Ca}^{2+}$ gains, and $\mathrm{K}^{+}$loss were significantly reduced in rats treated with 10 and $30 \mathrm{mg} / \mathrm{kg}$ sour cherry flavonoid-rich extract (Table 1).

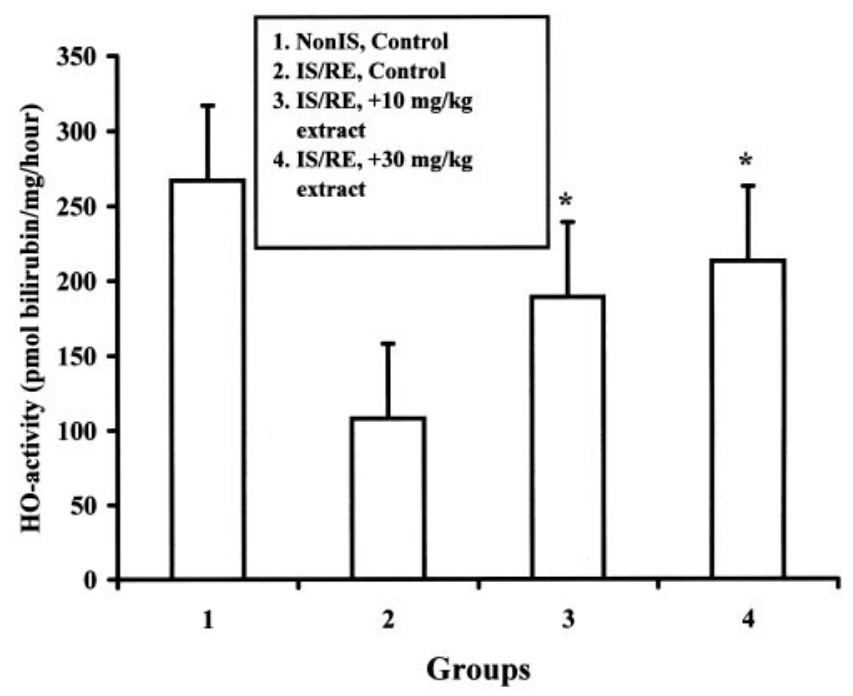

FIGURE 4. Effects of flavonoid-rich extract of sour cherry seeds on HO enzyme activities in ischemic/reperfused rat retina. Group 1: nonischemic control retina. Group 2: retinas were subjected to 90 minutes of ischemia followed by 24 hours of reperfusion. Group 3: conditions of ischemia/reperfusion protocol are the same as in the group 2, and rats were treated with $10 \mathrm{mg} / \mathrm{kg}$ flavonoid-rich sour cherry extract for 14 days. Group 4: conditions of ischemia/reperfusion protocol are the same as in the group 2, and rats were treated with $30 \mathrm{mg} / \mathrm{kg}$ flavonoidrich sour cherry extract for 14 days. $n=6$ in each group, mean \pm SEM, ${ }^{*} P<0.05$, comparisons were made to the ischemic/reperfused drugfree control group (group 2). 
TABle 1. Effects of Ischemia/Reperfusion and Sour Cherry Flavonoid-rich Extract on Cellular Sodium, Potassium, and Calcium Contents in Rat Retina

\begin{tabular}{|c|c|c|c|c|}
\hline \multirow[b]{2}{*}{ Groups } & \multirow[b]{2}{*}{$\begin{array}{c}\text { Nonischemic } \\
\text { Control } \\
(n=6)\end{array}$} & \multicolumn{3}{|c|}{$90 \mathrm{~min}$ ISA and $24 \mathrm{~h} \mathrm{RE}$} \\
\hline & & Untreated & $\begin{array}{c}\text { Extract* } \\
(10 \mathrm{mg} / \mathrm{kg})\end{array}$ & $\begin{array}{c}\text { Extract* } \\
(30 \mathrm{mg} / \mathrm{kg})\end{array}$ \\
\hline Sodium & $51.7 \pm 2.8$ & $94.2 \pm 3.2$ & $80.5 \pm 2.4$ & $70.3 \pm 4.1$ \\
\hline Potassium & $303.4 \pm 5.1$ & $229.6 \pm 4.2$ & $248.7 \pm 3.3$ & $263.8 \pm 5.9$ \\
\hline Calcium & $2.1 \pm 0.1$ & $4.8 \pm 0.2$ & $3.4 \pm 0.3$ & $2.9 \pm 0.4$ \\
\hline
\end{tabular}

Data are expressed as mean micromoles per gram dry weight \pm SEM. $n=6$ in each group. ISA, ischemia; RE, reperfusion.

${ }^{*} P<0.05$ compared with the values of untreated $(90 \mathrm{~min}$ ISA and 24 h RE) group.

\section{Discussion}

Occlusion of the central retinal artery is a true ophthalmic emergency, when each minute elapsed increases the chance of death of retina leading to vision loss. Although reperfusion is a prerequisite for the survival and recovery of ischemic tissue, it is emphasized that it is not without hazard, and reperfusioninduced injury could occur. Mammalian cells and tissues respond to injury by up- or downregulation of several stressrelated genes, the protein products of which, may participate in the protection against cellular injury. Although the importance of HO-mediated endogenous $\mathrm{CO}$ production has been identified recently as a protective mechanism in the regulation of ischemia/reperfusion-induced damage in various organs, ${ }^{23-26}$ the direct measurement of endogenous $\mathrm{CO}$ from retinal tissue, to our knowledge, has not yet been performed. Although the induction of HO-1 has recently been extensively studied at the level of gene transcription, ${ }^{27,28}$ the physiological function of this process is poorly understood in the context of its role in the mechanism and regulation of reperfusion-induced cellular injury. Therefore, in the present study, we have endeavored to obtain additional circumstantial evidence for the involvement of $\mathrm{HO}-1$-related endogenous $\mathrm{CO}$ production and its direct measurement in ischemic/reperfused rat retina.

Like nitric monoxide (NO), CO has been identified as an endogenous cellular messenger, and studies suggest an important role of CO in hemodynamic regulation. ${ }^{6}$ It has been shown that endogenously produced $\mathrm{CO}$ acts as a signal molecule ${ }^{2}$ and an activator of guanylate cyclase responsible for the generation of cGMP in the vascular tissue. ${ }^{29}$ These findings suggest that vessel wall-derived CO could serve as an endogenous regulator of vascular tone and platelet activity. Thus, it has been suggested that $\mathrm{CO}$ generated by heme catabolism may modulate the activity of the metabotropic receptor suspected to be neuroprotective during ischemic neuronal damage. ${ }^{30} \mathrm{CO}$ may also have the capacity to affect ischemic brain hemodynamics positively, through its inhibitory role on platelet aggregation, which may contribute to neuroprotection. ${ }^{31}$ In addition, the capacity of CO to induce cGMP, with upregulation of the cell survival signal bcl-2, together with inhibition of nuclear translocation of $\mathrm{p} 53$ protein, indicates an important role for the $\mathrm{HO}$ system in modulating cell death/survival signals. ${ }^{30}$ It is also of interest to note that $\mathrm{CO}$ binds and inactivates neuronal nitric oxide synthetase leading to a reduced production of nitric oxide by calcium influx into hypoxic neurons. ${ }^{32}$

In the present study involving measurement of retinal $\mathrm{CO}$ production, we now provide direct evidence consistent with the hypothesis that retinal CO production may play a key role in the development of reperfusion-induced damage through HO-1 protein induction in the retina. Using a flavonoid-rich extract of sour cherry seed to stimulate HO-1 protein expres- sion and endogenous CO production, we demonstrate that increased endogenous $\mathrm{CO}$ production is associated with the prevention of reperfusion-induced retinal damage. Mechanisms by which elevated HO-1 expression leads to the increase of endogenous CO production may involve the following: First, flavonoids, which are naturally occurring compounds, have been shown to modulate P-450-dependent metabolic activities in vitro and in vivo ${ }^{33,34}$ and to scavenge $\mathrm{O}_{2}{ }^{-}$- and $\mathrm{OH}-$-free radicals. Flavonoids also act as antioxidants ${ }^{35,36}$ and have antiinflammatory activity. ${ }^{37}$ The specific action of flavonoids may have been to increase the binding affinity of a substrate ${ }^{38}$ or to improve the electron transfer efficacy between NADPH-cytochrome P-450 reductase and the P-450 enzyme. The P-450 reductase, which transfers electrons from NADPH to $\mathrm{P}-450$ during P-450-dependent catalysis, is capable of reducing oxygen to yield superoxide anion, and the oxygenated intermediates of $\mathrm{P}-450$ itself can decompose in a side reaction to release superoxide anion. ${ }^{39}$ The second possible explanation for increased induction of HO-1 and CO formation may involve the elimination of reactive oxygen species and reducing their direct interaction with cellular components including gene transcription machinery. Therefore, with trapping of powerful oxidizing radical species, the rate of decay in HO-1 protein expression may decrease. Third, today, when so many advances are being made in molecular biology and cell physiology, we tend to lose sight of the potential importance of basic ions (e.g., $\mathrm{Na}^{+}, \mathrm{K}^{+}$, and $\mathrm{Ca}^{2+}$ ) in both experimental and clinical medicine. Our study emphasizes the importance of $\mathrm{Na}^{+}, \mathrm{K}^{+}$, and $\mathrm{Ca}^{2+}$ in the maintenance of ionic balance across cell membranes, because various clinical conditions are frequently complicated by vision loss that originates from the ionic imbalance through edema formation and apoptotic or necrotic cell death. Our findings provide a basis for inquiry but do not dissociate the different routes and pathways involved in the postischemic ion accumulation or loss in ischemic/reperfused retina. Thus, the connection between HO-1 gene and protein expression-related $\mathrm{CO}$ formation could modify cellular membrane ion transports, and an increase in HO-1 gene and encoded protein expression could protect against changes in cation concentrations caused by ischemia/reperfusion. Our results show that $\mathrm{Na}^{+}$and $\mathrm{Ca}^{2+}$ accumulate in retina. An increase in $\mathrm{CO}$ production by flavonoid-rich extract of sour cherry through the HO-1 protein expression resulted in a significant decrease in cellular $\mathrm{Na}^{+}$and $\mathrm{Ca}^{2+}$ contents leading to a significant reduction of edema formation ${ }^{11}$ and mitochondrial calcium-overload-induced cell death, which is a key mediator or signal of necrosis and/or apoptosis. ${ }^{40,41}$

In summary, the results show that a downregulation in HO-1 protein, HO-1-related CO production, and HO-1 enzyme activity could play a crucial role in the development of reperfusion-induced retinal damage. Thus, it is reasonable to suggest that interventions, which are able to increase endogenous CO production through the HO-1 system, could prevent the development of ischemia/reperfusion-induced injury including changes in cation concentration and edema formation in the retina. However, additional studies are needed to resolve the links in the apparent cascade of the up- and downregulation of ischemia/reperfusion-induced HO-1 protein expression, HO-1related $\mathrm{CO}$ generation, and enzyme activity in ischemic/reperfused retina.

\section{Acknowledgments}

The authors thank David Haines (University of George Washington, Department of Epidemiology, Washington, DC) for suggestions and a reading of the manuscript. 


\section{References}

1. Brouard S, Otterbein LE, Anrather J, et al. Carbon monoxide generated by heme oxygenase-1 suppresses endothelial cell apoptosis. J Exp Med. 2001;92:1015-1026.

2. Maines MD. The heme oxygenase system: a regulator of second messenger gases. Annu Rev Pharmacol Toxicol. 1997;37:517554.

3. Tenhunen R, Marver HS, Schmid R. Microsomal heme oxygenase: characterization of the enzyme. J Biol Chem. 1969;244:63886394 .

4. Tenhunen R, Ross ME, Marver HS, Schmid R. Reduced nicotinamide-adenine dinucleotide phosphate dependent biliverdin reductase: partial purification and characterization. Biochemistry. 1970;20:298-303.

5. McCoubrey WK, Huang TJ, Maines MD. Isolation and characterization of a cDNA from the rat brain that encodes hemoprotein heme oxygenase-3. Eur J Biochem. 1997;247:725-732.

6. Verma A, Hirsch DJ, Glatt CE, Ronnett GV, Snyder SH. Carbon monoxide: a putative neural messenger. Science. 1993;259:381384 .

7. Zakhary R, Gaine SP, Dinerman JL, Ruat M, Flavahan NA, Snyder SH. Heme oxygenase 2: endothelial and neuronal localization and role in endothelium-dependent relaxation. Proc Natl Acad Sci USA. 1996;93:795-798.

8. Keyse SM, Tyrrell RM. Heme oxygenase is the major 32-kDa stress protein induced in human skin fibroblasts by UVA radiation, hydrogen peroxide, and sodium arsenite. Proc Natl Acad Sci USA. 1989;86:99-103.

9. Ewing JF, Maines MD. Rapid induction of heme oxygenase 1 mRNA and protein by hyperthermia in rat brain: heme oxygenase 2 is not a heat shock protein. Proc Natl Acad Sci USA. 1991;88: $5364-5368$.

10. Bak I, Papp G, Turoczi T, et al. The role of heme oxygenase related carbon monoxide and ventricular fibrillation in ischemic/reperfused hearts. Free Rad Biol Med. 2002;33:639-648.

11. Szabo ME, Droy-Lefaix MT, Doly M, Carre C, Braquet P. Ischemia and reperfusion-induced histologic changes in the rat retina: demonstration of a free radical-mediated mechanism. Invest Ophthalmol Vis Sci. 1991;32:1471-1478.

12. Cook MN, Nakatsu K, Marks GS, et al. Heme oxygenase activity in adult rat aorta and liver as measured by carbon monoxide formation. Can J Physiol Pharmacol. 1995;73:515-518.

13. Pellacani A, Wiesel P, Sharma A, et al. Induction of heme oxygenase-1 during endotoxemia is downregulated by transforming growth factor-beta 1. Circ Res. 1998;83:396-401.

14. Yoshida T, Takahashi S, Kikuchi G. Partial purification and reconstitution of the heme oxygenase system from pig spleen microsomes. J Biochem. 1974;75:1187-1191.

15. Morita T, Perrella MA, Lee M, Kourembanas S. Smooth muscle cell-derived carbon monoxide is a regulator of vascular cGMP. Proc Natl Acad Sci USA. 1995;92:1475-1479.

16. Lowry OH, Rosebrough NJ, Farr AL, Randall RJ. Protein measurement with the Folin phenol reagent. J Biol Chem. 1951;193:265275.

17. Alto LE, Dhalla NS. Myocardial cation contents during induction of calcium paradox. Am J Physiol. 1979;237:713-719.

18. Szabo ME, Haines D, Garay E, et al. Antioxidant properties of calcium dobesilate in ischemic/reperfused diabetic rat retina. Eur J Pharmacol. 2001;428:277-286.

19. Doly M, Braquet P, Bonhomme B, Meyniel G. Effects of lipid peroxidation on the isolated rat retina. Ophthalmic Res. 1984;16: 292-296.

20. Tosaki A, Balint S, Szekeres L. Protective effect of lidocaine against ischemia and reperfusion-induced arrhythmias and shifts of myocardial sodium, potassium, and calcium content. J Cardiovasc Pharmacol. 1988;12:621-628.

21. Shakib M, Ashton N. Ultrastructural changes in focal retinal ischemia II. Br J Ophthalmol. 1966;50:325-354.
22. Juarez CP, Tso MOM, van Heuven WAJ, Hayreh MS, Hayreh SS. Experimental retinal occlusion: II. A clinico-pathologic correlative study of simultaneous occlusion of central retinal vein and artery. Int Ophthalmol. 1986;9:77-87.

23. Clark JE, Foresti R, Sarathchandra P, Kaur H, Green CJ, Motterlini R. Heme oxygenase-1-derived bilirubin ameliorates postischemic myocardial dysfunction. Am J Physiol. 2000;278:H643-H651.

24. Maines MD, Raju VS, Panahian N. Spin trap (N-t-butyl- $\alpha$-phenylnitrone)-mediated suprainduction of heme-oxygenase-1 in kidney ischemia/reperfusion model: role of the oxygenase in protection against oxidative injury. J Pharmacol Exp Ther. 1999;291:911919.

25. Sato K, Balla J, Otterbein L, et al. Carbon monoxide generated by heme oxygenase- 1 suppresses the rejection of mouse-to-rat cardiac transplants. J Immunol. 2001;166:4185-4194.

26. Takeda A, Onodera H, Sugimoto A, Itiyama Y, Kogure K, Shibahara S. Increased expression of heme oxygenase mRNA in rat brain following transient forebrain ischemia. Brain Res. 1994;666:120 124.

27. Jozkowicz A, Huk I, Nigisch A, et al. Heme oxygenase and angiogenic activity of endothelial cells: stimulation by carbon monoxide and inhibition by tin protoporphyrin-IX. Antioxid Redox Signal. 2003;5:155-162.

28. Naughton P, Hoque M, Green CJ, Foresti R, Motterlini R. Interaction of heme with nitroxyl or nitric oxide amplifies heme oxygenase-1 induction: involvement of the transcription factor Nrf2. Cell Mol Biol. 2002;48:885-894.

29. Durante W, Peyton KJ, Schafer AI. Platelet-derived growth factor stimulates heme oxygenase-1 gene expression and carbon monoxide production in vascular smooth muscle cells. Arteriosclerosis Thrombosis Vasc Biol. 1999;19:2666-2676.

30. Panahain N, Yoshiura M, Maines MD. Overexpression of heme oxygenase- 1 is neuroprotective in a model of permanent middle cerebral artery occlusion in transgenic mice. J Neurochem. 1999; 72:1187-1203.

31. Hussain AS, Marks GS, Brien JF, Nakatsu K. The soluble guanylyl cyclase inhibitor $1 \mathrm{H}-[1,2,4]$ oxadiazolo[4,3-alpha]quinoxalin-1-one (ODQ) inhibits relaxation of rabbit aortic rings induced by carbon monoxide, nitric oxide, and glyceryl trinitrate. Can J Physiol Pharmacol. 1997;75:1034-1037.

32. Durante W, Christoduolides N, Cheng K, Peyton KJ, Sunahara RK, Schafer AI. cAMP induces heme oxygenase-1 gene expression and carbon monoxide production in vascular smooth muscle. $A m J$ Physiol. 1997;273:H317-H323.

33. Huang MT, Johnson EF, Muller-Eberhard U, Koop DR, Coon MJ, Conney AH. Specificity in the activation and inhibition by flavonoids of benzo[a]pyrene hydroxylation by cytochrome P-450 isoenzymes from rabbit liver microsomes. J Biol Chem. 1981;256: 10897-10901.

34. Lasker JM, Huang MT, Conney AH. In vivo activation of zoxazolamine metabolism by flavone. Science. 1982;216:1419-1421.

35. Slater TF, Cheeseman KH, Davies MJ. Free radical scavenging properties of modulators of eicosanoid metabolism. Adv Prostaglandin Thromboxane Leukoc Res. 1987;17:1098-1102.

36. Torel J, Cillard J, Cillard P. Antioxidant activity of flavonoids and reactivity with peroxy radical. Phytochemistry. 1986;25:383-385.

37. Gabor M. Anti-inflammatory substances of plant origin. In: Vane JR, Ferreira SH, eds. Handbook of Experimental Pharmacology. Antiinflammatory Drugs. Vol. 50. Berlin: Springer, 1979;698-739.

38. Johnson EF, Schwab GE, Vickery LE. Positive effectors of the binding of an active site-directed amino steroid to rabbit cytochrome P-450 3c. J Biol Chem. 1988;263:17672-17677.

39. Halliwell B, Gutteridge JMC. Free Radicals in Biology and Medicine, New York: Oxford University Press; 1985;107-117.

40. Kilic F, Handelman GJ, Traber K, Tsang K, Packer L, Trevithick JR. Modelling cortical cataractogenesis XX. In vitro effect of alphalipoic acid on glutathione concentrations in lens in model diabetic cataractogenesis. Biochem Mol Biol Int. 1998;46:585-595.

41. Kilic F, Trevithick JR. Modeling cortical cataractogenesis. XXIX. Calpain proteolysis of lens fodrin in cataract. Biochem $\mathrm{Mol}$ Biol Int. 1998;45:963-978. 